\section{Stability Analysis of Bitemarks in Different Conditions of Time and Temperature and Its Reliability as Evidence in Criminal Investigations}

Laís Gomes de Araújo ${ }^{1}{ }^{\circ}$, Tamara Soledad Frontanilla Recalde ${ }^{2}$, , Victor Jacometti ${ }^{2}$ (D) Paula Barreto Costa $^{2}{ }^{-}$, Ricardo Henrique Alves da Silva ${ }^{1,2}{ }^{(0)}$
'School of Dentistry of Ribeirão Preto, USP - Universidade de São Paulo, Ribeirão Preto, SP, Brazil ${ }^{2}$ School of Medicine of Ribeirão Preto, USP - Universidade de São Paulo, Ribeirão Preto, SP, Brazil

Correspondence: Ricardo Henrique Alves da Silva, Avenida do Café, s/n, 14040-904 Ribeirão Preto, SP, Brasil. Tel: +55-16-3315-3969. e-mail: ricardohenrique@usp.br

\begin{abstract}
The objective of this study was to evaluate the stability of bite marks in foods in different conditions of time and temperature and their reliability as evidenced in criminal investigations. Sampling came from 20 subjects, who were instructed to bite five pieces of cheese and five pieces of chocolate. Bites were produced by the anterior teeth, from canine to canine, and the volunteers had their dental arches molded to obtain plaster models that were used for later comparison. The samples produced by each participant were stored and analyzed according to the temperature (room and refrigerator) and time period (immediately after, three days, seven days). The linear model with mixed effects using R Core Team and SAS Statistical Software were used for the statistical analysis. The results of this study reveal that the storage temperature of these materials does not exert a significant influence. Both chocolate and cheese showed better results when measurements were made shortly after, however the chocolate showed to be more stable in longer periods of time. By means of this study, it was possible to demonstrate that the storage temperature does not exert a significant influence. However, the bite marks found in foods with greater dimensional stability and short time intervals, are more reliable and allow their use as evidence in criminal investigations. Still, due to the limitations presented, we recommend its use for the exclusion of possible suspects and not for the suspects identification.
\end{abstract}

Key Words: human bites, forensic dentistry, evidence-based dentistry, human identification.

\section{Introduction}

Identity is defined as the sum of the morphophysiological and psychic characteristics of a particular person that make it unique (1). In Forensic Dentistry, human identification is one of the main topics of study since biological materials such as teeth and saliva have the potential to contribute directly to the identification of an individual, both by analysis of dental methods and by means of genetic tests (2).

A potential area of research in dental science involving human identification is the study of the bite marks. The moment an individual performs the bite act, the impression of each tooth is engraved on the surface, revealing a unique identity of that generated mark (3). Based on the assumption that there are no equal dental patterns between two people, even for univiteline twins, bite marks can be considered unique (4-5).

Their records are often associated with criminal matters and may even link a suspect to the crime scene. Bitemarks on food and inanimate objects are documented in the literature and in court records of different countries, which have used different approaches and techniques to analyze the evidence found (6).
The forensic dentistry plays an extremely important role in criminal cases where a vestige to be analyzed is a bite mark. By means of expert analysis, it is possible to link or exclude a suspect to the scene of the crime. Knowing the stability of bite marks, thus becomes indispensable for considering their use in criminal investigations (7).

The information generated by examining the bitemarks can be obtained through dental tests (physical evidence) and DNA tests (biological evidence) (8). Physical evidence can be processed through metric analysis, which corresponds to the measurements, and physical pairing, performed through the overlap of the images from the characteristics observed in the bite (9). Biological evidence can be analyzed through the DNA obtained from the saliva contained in the bite marks (10).

The great majority of published research on food bitemarks and sucking acts were carried out in temperate countries (11). It is of fundamental importance to know the conditions of the analysis of this trace in countries with a tropical climate, such as Brazil. Therefore, the objective of this study was to evaluate the stability of bitemarks in foods in different conditions of time and temperature and their reliability as evidenced in criminal investigations. 


\section{Material and Methods}

The project was approved by the Ethics Committee of the School of Dentistry of Ribeirão Preto, University of São Paulo. Sampling came from 20 volunteers, ten males and ten females, who were instructed to bite five pieces of mozzarella cheese and five pieces of milk chocolate, totaling 10 samples per individual. Only 20 individuals were studied in this preliminary study, which could be seen as a limitation of our study. These were distributed equally between both sexes.

Food bites were produced by the anterior teeth, from canine to canine, and the subjects of the research had their dental arches molded to obtain plaster models that were used for later comparison. The samples produced by each participant were stored and analyzed according to temperature (room temperature: $24-37^{\circ} \mathrm{C}$ and refrigerator: 2-4 ${ }^{\circ} \mathrm{C}$ ) and time period (immediately after consumption, three days, seven days), as shown in Table 1.

Subsequently, food were molded through rectangular trays made of acrylic resin (Jet Acrylic powder and liquid, São Paulo, SP, Brazil) in a rectangular format with dimensions of approximately $5 \mathrm{~cm}$ high $\times 5 \mathrm{~cm}$ wide $\times 8$ $\mathrm{cm}$ long, and samples for the three and seven days analysis $\vec{s}$ were stored in a plastic container with a lid at different temperatures (room and refrigerator), and these were also molded as soon as they reached the pre-established time period.

The molding of each food was done using the alginate (Jeltrate ${ }^{\circledast}$, Dustless, Petrópolis, RJ, Brazil) to the fact that the low cost makes it possible to be available in legal medicine institutes. After that, were made models using plaster type IV. From the plaster models of the dentitions in question and the plaster models of the bitten foods, the metric analyzes of the bitemarks were performed by a single examiner, who did not know the identity of the volunteers.

Evaluations occurred at different times, with time

Table 1. Sample groups according to time and temperature

\begin{tabular}{lccc}
\hline Time & Food & $\begin{array}{c}\text { Room } \\
\text { emperature }\end{array}$ & $\begin{array}{c}\text { Refrigerator } \\
\text { temperature }\end{array}$ \\
\hline \multirow{2}{*}{ Immediately } & Cheese & 1 sample & $*$ \\
& Chocolate & 1 sample & $*$ \\
3 days & Cheese & 1 sample & 1 sample \\
& Chocolate & 1 sample & 1 sample \\
7 days & Cheese & 1 sample & 1 sample \\
& Chocolate & 1 sample & 1 sample \\
\hline
\end{tabular}

* Samples analyzed immediately were not subjected to refrigeration conditions. intervals of two weeks for each method applied. A digital caliper (Digital Caliper, Cixi Xinzheng Trade Co. Ltd., Zhejiang, China) was used for the metric analysis of bitemarks in plaster models (dental arches and food) considering the intercanine distances and mesiodistal distances of upper anterior teeth and lower anterior teeth, recorded on bites of each food and in the dentitions of the volunteers (Variable 1-14) and recorded in a Microsoft Excel worksheet.

For the statistical analysis, the software used were $\mathrm{R}$ Core Team (R Foundation for Statistical Computing, Vienna, Austria, 2016) and SAS Statistical Software (version 9.3; SAS Institute, Inc. Cary, NC, USA). The variables V1 to V12 were compared using the linear model with mixed effects through the MIXED procedure package of SAS, with a confidence interval of $95 \%$. The $\mathrm{V} 1$ is the upper intercanine distance, $\mathrm{V} 14$ is the lower intercanine distance and the variables $\mathrm{V} 2$ to $\mathrm{V} 13$ represent the mesiodistal distances of teeth $23,22,21,11,12,13,33,32,31,41,42$ and 43 , respectively. This model considers a random effect per individual, stating that a single individual has five measurements taken in each of the two different materials, according to the moment of measurement and the storage temperature. This calculus is done by the following formula: $\mathrm{pij}=$ measurementij/basal, where $\mathrm{i}=$ basal $(0,1)$, referring to the time the measurement was taken (basal moment, three days, seven days, respectively) and $\mathrm{j}=$ basal $(0,1)$, referring to the temperature that the food was stored (basal, room temperature, refrigerator, respectively).

The measurement performed immediately after the bite was taken as basal, having its value equal to 1 , and the achievers had values that reflected the dimensional modifications for more and to less that the measures presented, before the time, temperature and food studied (cheese or chocolate). In this way, it was possible to visualize how the variables change over time in relation to the basal moment and in each material.

\section{Results}

The results of these comparisons are set forth in Table 2 and Figures 1-5. The upper and lower intercanine distances and the mesiodistal distances of the maxillary rigth and left central and lateral incisors were considered for analysis because the lower teeth did not present significant differences.

In table 2 we can observe the comparisons between measurements (V1-V14), material, temperature and time. Moment 0 always gets value 1 because it is the immediate measurement after bite. It was called basal value and it was held as a threshold to observe proportion changes within materials in each temperature and time. Then, in the other moments, this value varies around the base number, 
Table 2. Comparisons between measurements, material, temperature and time using the linear model with mixed effects. V1 = Upper intercanine distance; V3-V6 = mesiodistal distance between tooth 22,21,11 and 12, respectively; V14 = Lower intercanine distance

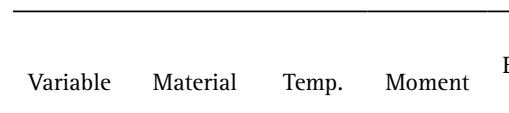

Confidence

ratio \begin{tabular}{l} 
Inf. Sup. \\
\cline { 3 - 4 }
\end{tabular}

V1

V1

$\mathrm{V} 1$

V1

V1

V1

V1

V1

V1

$\mathrm{V} 1$

V3

V3

V3

V3

Cheese

Chocolate

Cheese

$\begin{array}{lllll}\text { Room } & 3 \mathrm{~d} & 0.96 & 0.93 & 0.99\end{array}$

$\begin{array}{llll}7 \mathrm{~d} & 0.97 & 0.94 & 1.00\end{array}$

Immed $\quad 1.00 \quad 0.97 \quad 1.03$

$\begin{array}{lllll}\text { Refrig. } & 3 \mathrm{~d} & 0.97 & 0.94 & 1.00\end{array}$

$\begin{array}{llll}7 \mathrm{~d} & 0.94 & 0.91 & 0.96\end{array}$

Immed

1.00

$0.97 \quad 1.03$

Room

3

7

$$
0.97
$$

$0.94 \quad 1.00$

Immed

1.00

$0.96 \quad 1.03$

Immed

1.00

$0.97 \quad 1.03$

Refrig.

$3 \mathrm{~d}$

$\begin{array}{llll}7 \mathrm{~d} & 1.04 & 1.00 & 1.07\end{array}$

Immed $\quad 1.00 \quad 0.94 \quad 1.06$

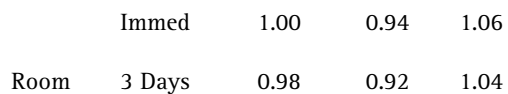

7 Days

0.96

$0.90 \quad 1.03$

Immed

1.00

$0.94 \quad 1.06$

Refrig.

3 Days

7 Days

1.01

$0.96 \quad 1.07$

V3

V3

V3

V3

V3

Chocolate

Room

Immed

1.00

$0.88 \quad 1.00$

3 Days

0.98

$0.94 \quad 1.06$

7 Days

Immed $\quad 1.00 \quad 0.94 \quad 1.06$

Refrig

$\begin{array}{llll}3 \mathrm{~d} & 1.05 & 1.00 & 1.11\end{array}$

$\begin{array}{llll}7 \mathrm{~d} & 1.00 & 0.95 & 1.06\end{array}$

V3

V4

V4

V4

V4

Cheese

V4

V4

V4

V4

V4

\begin{tabular}{|c|c|c|c|c|}
\hline & Immed & 1.00 & 0.96 & 1.04 \\
\hline \multirow[t]{3}{*}{ Refrig. } & $3 \mathrm{~d}$ & 1.00 & 0.96 & 1.05 \\
\hline & $7 \mathrm{~d}$ & 0.99 & 0.94 & 1.03 \\
\hline & Immed & 1.00 & 0.95 & 1.05 \\
\hline \multirow[t]{3}{*}{ Room } & $3 \mathrm{~d}$ & 0.99 & 0.94 & 1.04 \\
\hline & $7 \mathrm{~d}$ & 1.01 & 0.96 & 1.07 \\
\hline & Immed & 1.00 & 0.95 & 1.05 \\
\hline \multirow[t]{3}{*}{ Refrig. } & $3 \mathrm{~d}$ & 0.99 & 0.94 & 1.04 \\
\hline & $7 \mathrm{~d}$ & 0.97 & 0.92 & 1.03 \\
\hline & Immed & 1.00 & 0.95 & 1.05 \\
\hline \multirow[t]{3}{*}{ Room } & $3 d$ & 1.01 & 0.96 & 1.06 \\
\hline & $7 \mathrm{~d}$ & 1.01 & 0.96 & 1.06 \\
\hline & Immed & 1.00 & 0.95 & 1.05 \\
\hline \multirow[t]{2}{*}{ Refrig. } & $3 d$ & 0.97 & 0.92 & 1.02 \\
\hline & $7 \mathrm{~d}$ & 0.98 & 0.93 & 1.03 \\
\hline
\end{tabular}

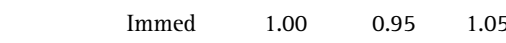

$\begin{array}{lllll}\text { Room } & 3 \mathrm{~d} & 1.00 & 0.94 & 1.05\end{array}$

$\begin{array}{llll}7 \mathrm{~d} & 1.01 & 0.96 & 1.07\end{array}$

Cheese

Immed $\quad 1.00 \quad 0.95 \quad 1.05$

$\begin{array}{lllll}\text { Refrig } & 3 \mathrm{~d} & 1.01 & 0.96 & 1.06\end{array}$

$\begin{array}{llll}7 \mathrm{~d} & 0.93 & 0.87 & 0.98\end{array}$

Immed $\quad 1.00 \quad 0.95 \quad 1.05$

$\begin{array}{lllll}\text { Room } & 3 \mathrm{~d} & 1.07 & 1.02 & 1.12\end{array}$

Chocolate

$\begin{array}{llll}7 \mathrm{~d} & 1.05 & 0.99 & 1.10\end{array}$

Immed $\quad 1.00 \quad 0.95 \quad 1.05$

$\begin{array}{lllll}\text { Refrig. } & 3 \mathrm{~d} & 1.11 & 1.06 & 1.17\end{array}$

$\begin{array}{llll}7 \mathrm{~d} & 1.01 & 0.95 & 1.06\end{array}$

Immed $\quad 1.00 \quad 0.96 \quad 1.04$

$\begin{array}{lllll}\text { Room } & 3 \mathrm{~d} & 1.00 & 0.97 & 1.04\end{array}$

Cheese

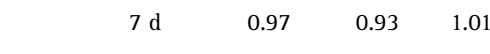

Immed $\quad 1.00 \quad 0.96 \quad 1.04$

$\begin{array}{lllll}\text { Refrig. } & 3 \mathrm{~d} & 0.99 & 0.96 & 1.03\end{array}$

$\begin{array}{llll}7 \mathrm{~d} & 0.94 & 0.90 & 0.97\end{array}$

Immed $\quad 1.00 \quad 0.96 \quad 1.04$

$\begin{array}{lllll}\text { Room } & 3 \mathrm{~d} & 1.02 & 0.98 & 1.06\end{array}$

Chocolate

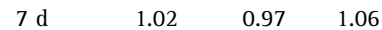

Immed $\quad 1.00 \quad 0.96 \quad 1.04$

$\begin{array}{lllll}\text { Refrig. } & 3 \mathrm{~d} & 1.00 & 0.96 & 1.04\end{array}$

$\begin{array}{llll}7 \mathrm{~d} & 1.03 & 0.99 & 1.07\end{array}$ 
indicating an increase or decrease in the measurement taken, depending on the observed value (higher or lower than 1). Furthermore, intervals of confidence that include the value 1 do not bring evidence of difference between the observed moment and the baseline. Nonetheless, when this interval range do not include value 1 , there is evidence of difference between the observed moment and the baseline moment. When the interval has values above 1 , it indicates evidence that the value of the observed moment is greater than the basal value. Intervals with values below 1 indicate evidence that the value of the observed moment is lower than baseline.

The graphs show the behavior of the measurements, according to the material (cheese or chocolate), time (immediate, 3 days and 7 days) and temperature (room or refrigerator). The respective confidence intervals of each measure are shown by vertical lines at the points determined by the measures performed. Values that have confidence
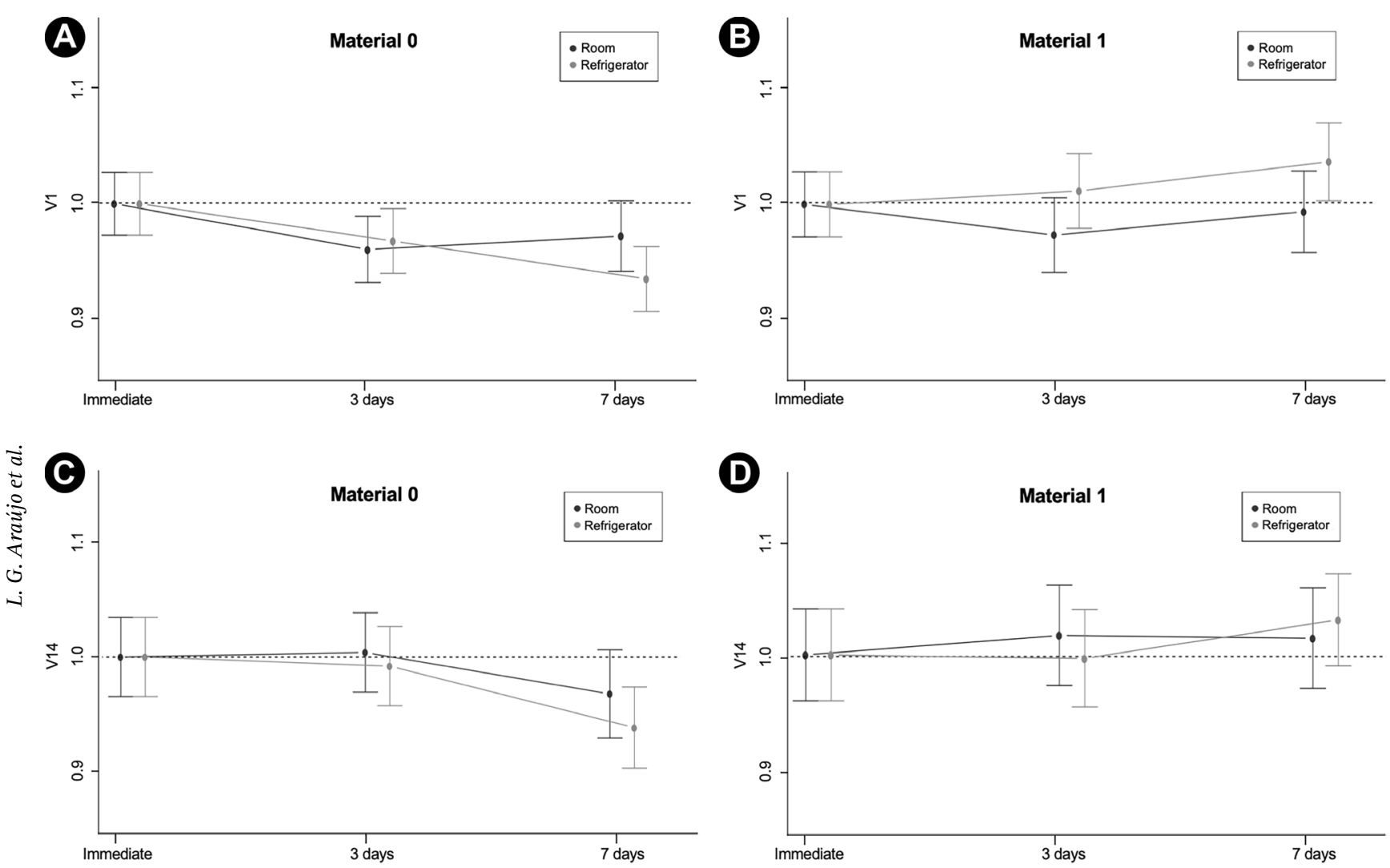

Figure 1. Comparison of the upper intercanine distances in cheese (A) and chocolate (B) and lower intercanine distance in cheese (C) and chocolate in different conditions of time and temperature.
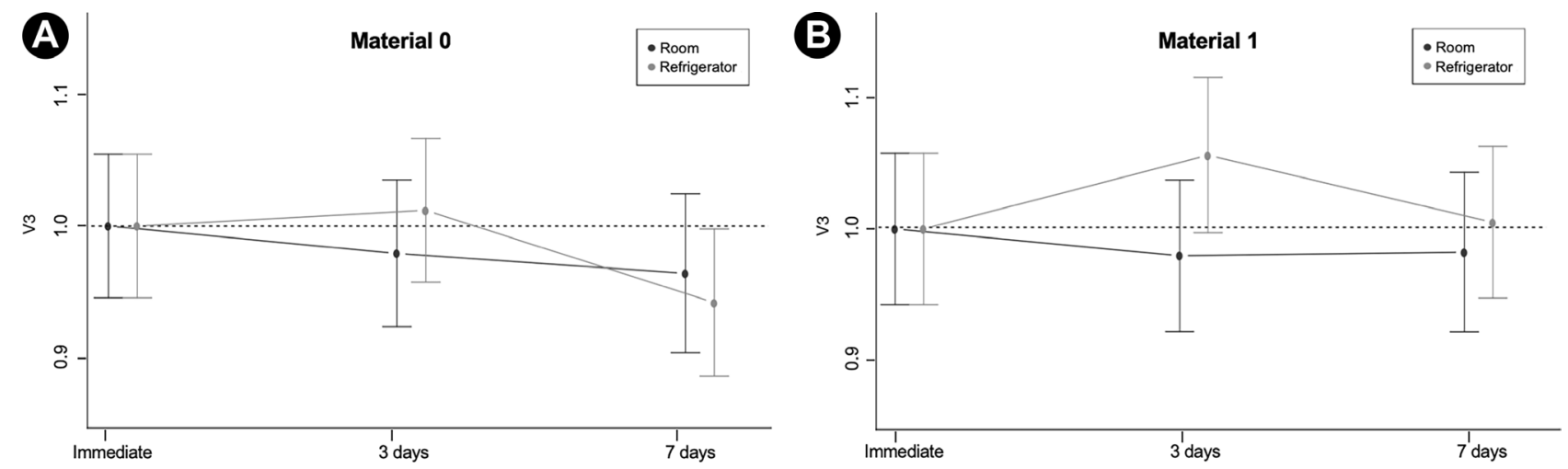

Figure 2. Comparison of the mesiodistal distance of tooth 12 in cheese (A) and in chocolate (B) under different conditions of time and temperature. 
intervals that lie outside the dotted line (baseline), have demonstrated evidence of changes in measurements made relative to their reference (baseline $=1$ ), in said material, temperature and time. The size of the confidence interval indicates the magnitude of this evidence.

The results provided evidence that the storage temperature of these materials does not exert a significant influence. Both chocolate and cheese showed better results
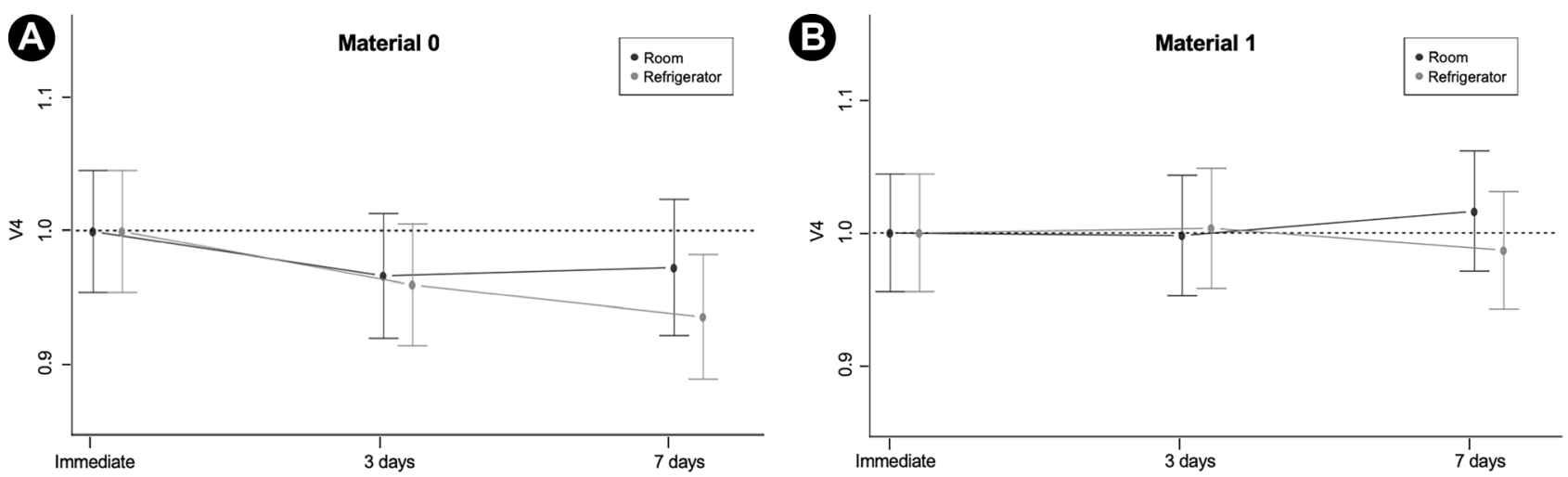

Figure 3. Comparison of the mesiodistal distance of tooth 21 in cheese (A) and in chocolate (B) under different conditions of time and temperature.
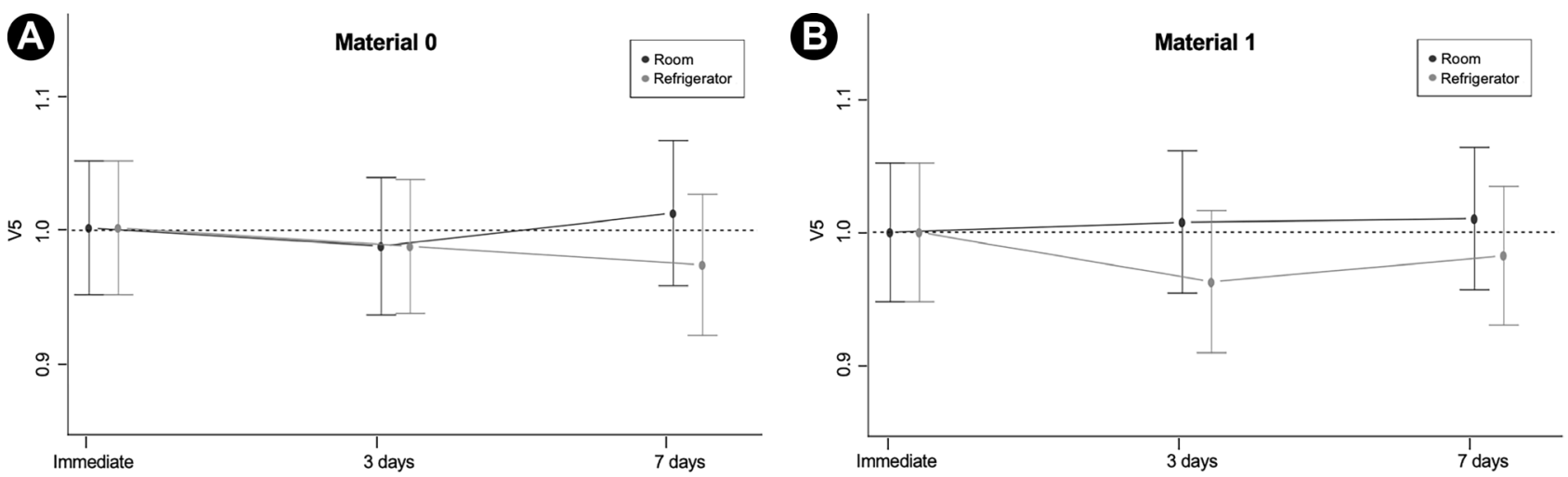

Figure 4. Comparison of the mesiodistal distance of tooth 11 in cheese (A) and in chocolate (B) under different conditions of time and temperature.
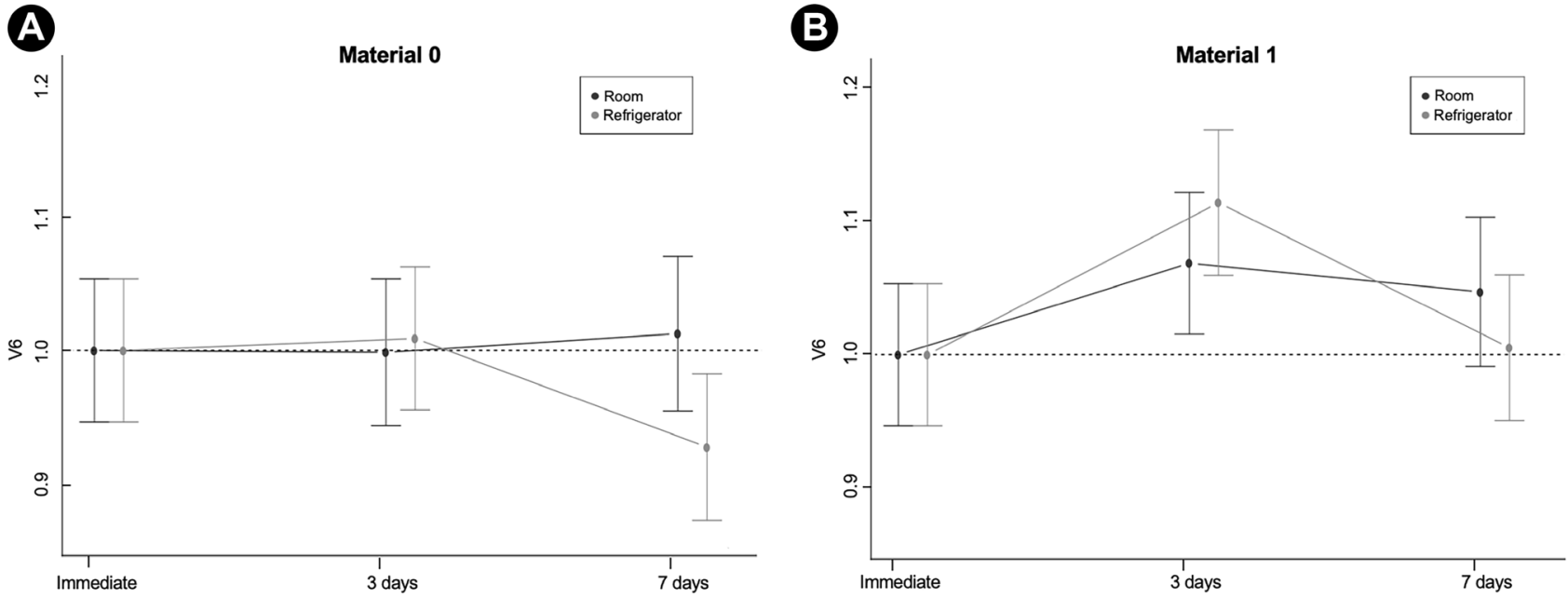

Figure 5. Comparison of the mesiodistal distance of the tooth 12 in the cheese (A) and in chocolate (B) under different conditions of time and temperature. 
when measurements were made shortly after, however the chocolate showed to be more stable in longer periods of time ( 3 and 7 days).

\section{Discussion}

The analysis of bitemarks is a complex topic and involves constant debates in Forensic Dentistry (12-13). Liable to be found at a crime scene, bitemarks in many cases may be the only evidence in forensic investigations (14). However, many convictions based on descriptive analysis were challenged in the Courts, considering the empirical tests, subjective and with the possibility of errors in this technique (15).

And hence the theory of uniqueness is a strong point used in the analysis of bite marks to convince the court of law that a dentition in one individual is different from another human dentition (3), however this has not been scientifically established (5). Some authors defend the effectiveness of the technique and recommend its use in criminal investigations, including in forensic cases (16-17). However, others discuss the uniqueness of bite marks and recommend their use only to narrow down the search universe; that is, the inclusion or exclusion of the different suspects $(5,14,15)$.

Thus, many methods have been developed to be used in conjunction with the accepted protocols in the literature for bitemarks expertise. These proposals generally manual, semi-automatic and fully automatic approaches (12).

Conventional techniques for the analysis of physical evidence are based on comparison methods, including metric size, shape and position of teeth, physical pairing, and direct manual overlap can be performed on the plaster models of suspects and bitemarks; or the superposition of photographic images, performed directly on the models, or on digitized images models using computer software (15).

For the analysis of the physical evidence, as Naether et al (17), bitemarks produced in food, in different time conditions (immediate, three days and seven days) and temperature (environment and refrigerator) were studied. Measurements were directly taken with the digital caliper from the plaster models of both the bitten foods and the dental arches. The photograph could be considered as another option for the analysis of these traces, through the superposition of images (18). Although the photographs have the advantage of relative temporal permanence, it is important to emphasize that they represent two dimensions' images, with bite marks being three-dimensional. Thus, features such as depth cannot be analyzed, which is why some authors justify the difficulty of using this digital artifice to analyze the bite mark (19).

With recent advances in research, methodologies that analyze and compare the bite mark in $3 \mathrm{D}$ are more relevant because, in a real scenario, the evidence has three- dimensional forms (20). Radford et al. (21) have confirmed that research testing bites on flat wax plates does not yield reliable results, since the action of mouth opening for bite on 3D object involves not only the temporomandibular joint but also the atlantooccipital resulting in a bite different.

González et al. (22) carried out a study that evaluates the latest techniques of bitemarks analysis and the results showed that the techniques that use 3D comparison are more accurate than those that use comparative analysis with only photographs, since the marks that are analyzed are three-dimensional.

With regard to possible changes in food relative to the time elapsed for analysis, in this study, the chocolate samples showed to be more stable than the cheese for analysis in the periods of 3 and 7 days. Ali et al. (23) carried out a study demonstrating that chocolate was a stable food in all the time periods in question, with no significant differences between them, but the pre-established times were shorter (immediately after, $3 \mathrm{~h}$ and $6 \mathrm{~h}$ ) in relation to those proposed in this study, which may explain this discrepancy between the results. Dorion (24) further stated that semi-hard chocolate is probably one of the best foods for analysis of bitemarks impressions due to its three-dimensional stability.

Food is subject to considerable shrinkage and distortion, which may compromise the study of dental impressions (20). When the cheese is kept exposed to air and at room temperature, it loses considerable amount of water and fat, and can also modify its conformation. According to Cameron and Sims (25), the intensity of dehydration varies according to the cheese types. Bullets and chocolates can preserve dental marks with good quality, although the quality decreases with increasing room temperature in which they are found.

Considering the high temperatures in Brazil, in this study it was considered as a variable the temperature, in order to evaluate if the food storage in the refrigerator would betray better results, thus justifying the refrigeration of these traces, when the analysis could not be done immediately. However, our results did not present significant influences that justify this practice.

Even though food may undergo changes in its structure over time, when this factor is considered to be minimal (often microscopic), it will not affect the analysis of bitemarks (17) and consequently it would be possible to link the suspect to the scene. The numerical limits of deformation, retraction and distortion that could significantly affect the results of the physical analyzes have not been determined in the literature (20).

Bitemarks can be an interesting evidence to be used in criminal investigations and have the potential to assist in elucidating cases. However, many authors state that the 
accuracy and reliability of identification increase when possible morphometric analysis methodologies are used in a manner intercalated (26). Thus, in order to minimize possible expert errors, it is important to carry out the calibration of the techniques and especially the faithful application of the methods to be performed.

In addition, as in expert practice, there are often no indicative elements that allow to determine with certainty the lapse of time lapsed and taking into account that the stability of the bitemarks is related to the type of food and to the time lapse, they should be used more to the exclusion of potential suspects rather than identification.

Based on the results presented, it was possible to demonstrate that the storage temperature does not exert a significant influence. However, the bitemarks found in food with greater dimensional stability and short time intervals, are more reliable and allow their use as evidence in criminal investigations. Still, due to the limitations presented, we recommend its use for the exclusion of possible suspects and not for the suspect identification.

\section{Resumo}

0 objetivo deste estudo foi avaliar a estabilidade das marcas de mordida em alimentos em diferentes condições de tempo e temperatura e sua confiabilidade como evidência em investigações criminais. A amostragem foi composta por 20 individuos, que foram instruidos a morder cinco pedaços de queijo e cinco pedaços de chocolate. As mordidas foram produzidas pelos dentes anteriores, de canino a canino, e os sujeitos da pesquisa tiveram seus arcos dentais moldados para obter modelos que foram usados para posterior comparação. As amostras produzidas por cada participante foram armazenadas e analisadas de acordo com a temperatura (ambiente e geladeira) e período de tempo (imediatamente, após três dias e sete dias). Para a análise estatística, utilizou-se o modelo linear com efeitos mistos, utilizando R Core Team e SAS Statistical Software. Os resultados deste estudo revelam que a temperatura de armazenamento desses materiais não exerce influência significativa. Tanto o chocolate quanto o queijo apresentaram melhores resultados quando as mensurações foram feitas logo após, porém o chocolate mostrou-se mais estável em períodos mais longos. Por meio deste estudo, foi possivel demonstrar que a temperatura de armazenamento não exerce influência significativa. Entretanto, as marcas de mordida encontradas em alimentos com maior estabilidade dimensional e intervalos de tempo curtos são mais confiáveis e permitem seu uso como evidência em investigações criminais. Ainda assim, devido às limitações apresentadas, recomendamos seu uso para a exclusão de possíveis suspeitos e não para a individualização dos mesmos.

\section{Acknowledgements}

To FAPESP, for the financial support and the Technical Training grant, which allowed the execution of the project.

\section{References}

1. Vanrell. Odontologia Legal e Antropologia Forense. Rio de Janeiro: Guanabara Koogan; 2008.

2. Chidambaram R. Forensic Odontology: A Boon to Community in Medico-legal Affairs. JNMA J Nepal Med Assoc 2016;54:46-54.

3. Saks MJ, Albright T, Bohan TL, Bierer BE, Bowers CM, Bush MA, et al. Forensic bitemark identification: weak foundations, exaggerated claims, J Law Biosci 2016;3:538-575.

4. Krishan K, Kanchan T, Garg AK. Dental Evidence in Forensic
Identification - An Overview, Methodology and Present Status. Open Dent J 2015;31:250-256.

5. Franco A. Unique or not unique? That is the question! - Opinion article on a bitemark scope. RBOL 2015;2:126-131.

6. Beena VT, Divya Gopinath, Heera R, Rajeev R, Sivakumar R. Bite marks from the crime scene- an overview. J Oral Maxillofac Pathol 2012;31:192-197.

7. Macdonald DG. Bite mark recognition and interpretation. J Forensic Sci Soc 1974;14:229-233.

8. Sweet D, Pretty IA. A look at forensic dentistry - Part 2: teeth as weapons of violence - identification of bitemarks perpetrators. $\mathrm{Br}$ Dent J 2001;190:415-418.

9. Sheasby DR, Macdonald DG. A forensic classification of distortion in human bite marks. Forensic Sci Int 2001;122:75-78.

10. Zapico SC, Menéndez ST. Human mitochondrial DNA and nuclear DNA isolation from food bite marks. Arch Oral Biol 2016;70:67-72.

11. Al-Talabani N, Al-Moussawy ND, Baker FA, Mohammed HA. Digital analysis of experimental human bitemarks: application of two new methods. J Forensic Sci 2006;51:1372-1375.

12. Evans $S$, Noorbhai $S$, Lawson $Z$, Stacey-Jones $S$, Carabott $R$. Contrast enhancement of bite mark images using the grayscale mixer in ACR in Photoshop ${ }^{\circledR}$. J Forensic Sci 2013;58:804-810.

13. Rajshekar $M$, Kruger $E$, Tennant $M$. Bite marks: Understanding the role of general practitioners in forensic identification. J. Int Oral Health 2012;4:1-7.

14. Tuceryan M, Li F, Blitzer HL, Parks ET, Platt JA. A framework for estimating probability of a match in forensic bite mark identification. J Forensic Sci 2011;1:83-90.

15. van der Velden A, Spiessens M, Willems G. Bite mark analysis and comparison using image perception technology. J Forensic Odontostomatol. 2006;24:14-17.

16. Nascimento $M$, Sarmento $V$, Beal V, Galvão L, Marques J. Identification of individuals through bite marks in foods using reverse engineering and rapid prototyping: simulated case. Arq Odontol. 2012; 48:134-141.

17. Marques JAM. Methodologies for identification of bite marks. Sao Paulo. Dissertation [Master's Degree in Legal Deontology and Dentistry] University of São Paulo; 2004. Available from: www. teses.usp.br/teses/disponiveis/23/23142/tde.../TeseToda.pdf -

18. Naether $S$, Buck U, Campana L, Breitbeck $R$, Thali M. The examination and identification of bite marks in foods using $3 D$ scanning and 3D comparison methods. Int J Legal Med 2012;126:89-95.

19. Maior JRS, Braga Netto ABA, Gomes RGC, Genú PR. The photography application in bite marks. Int J Dent;2007;6:21-24.

20. Manica S. Difficulties and limitations of using bite mark analysis in Forensic Dentistry -a lack of science. RBOL 2016;3:83-91.

21. Radford G, Kieser JA, Bernal V, Waddell JN, Forrest A. Biomechanical approach to human bitemark reconstruction. J Forensic Odontostomatol 2009;27:33-36

22. Gonzalez MEL, Sánchez Sánchez JA, Cienfuegos-Jovellanos BB. Bite marks: latest techniques of analysis. Revista de La Escuela de Medicina Legal 2006;47-53.

23. Ali IK, Sansare K, Karjodkar FR. Analysis of Intercanine Distance and Dimensional Changes in Bite Marks on Foodstuffs Using Cone Beam Computed Tomography. Am J Forensic Med Pathol. 2018.

24. Dorion RBJ. Nonperishables and perishables. In: Dorion RBJ, editor. Bitemark evidence. A color atlas and text. 2nd edn. Boca Raton, FL:CRC Press 2011;159-163.

25. Cameron JM, Sims BG. Forensic dentistry. Edinburgh: Churchill Livingstone. 1973:157p.

26. Bernitz $\mathrm{H}, \mathrm{O}$ wen $\mathrm{JH}$, van Heerden WF, Solheim T. An integrated technique for the analysis of skin bite marks. J Forensic Sci. 2008;53:194-198. 
Braz Dent J 30(3) 2019 